Nicholas Rescher

Philosophische Vorstellungen

Studien über die menschliche Erkenntnis 

Nicholas Rescher

\section{Philosophische Vorstellungen}

Studien über die menschliche Erkenntnis

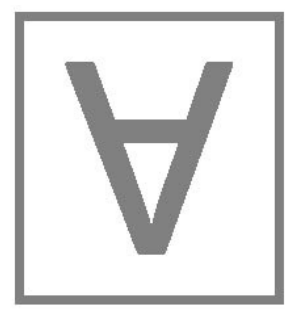

ontos

verlag 
Bibliographic information published by Deutsche Nationalbibliothek

The Deutsche Nationalbibliothek lists this publication in the Deutsche Nationalbibliographie; detailed bibliographic data is available in the Internet at http://dnb.ddb.de

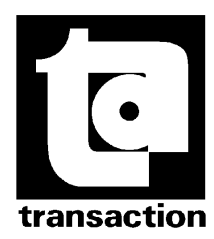

North and South America by

Transaction Books

Rutgers University

Piscataway, NJ 08854-8042

trans@transactionpub.com

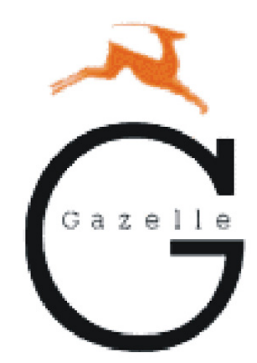

United Kingdom, Eire, Iceland, Turkey, Malta, Portugal by

Gazelle Books Services Limited

White Cross Mills

Hightown

LANCASTER, LA1 4XS

sales@gazellebooks.co.uk

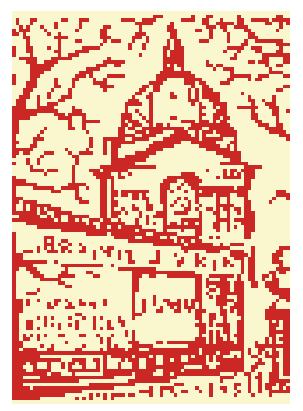

Livraison pour la France et la Belgique:

Librairie Philosophique J.Vrin

6 , place de la Sorbonne; F-75005 PARIS

Tel. +33 (0)1 435403 47; Fax +33 (0)1 43544818

www.vrin.fr

\author{
(C)2012 ontos verlag \\ P.O. Box 15 41, D-63133 Heusenstamm \\ www.ontosverlag.com
}

ISBN 978-3-86838-169-6

2012

No part of this book may be reproduced, stored in retrieval systems or transmitted in any form or by any means, electronic, mechanical, photocopying, microfilming, recording or otherwise without written permission from the Publisher, with the exception of any material supplied specifically for the purpose of being entered and executed on a computer system, for exclusive use of the purchaser of the work

Printed on acid-free paper

FSC-certified (Forest Stewardship Council)

This hardcover binding meets the International Library standard

Printed in Germany

by CPI buch bücher gmbh 